\title{
Revitalization of Malay Cultural Values in Regional Regulation of Spatial and Region in Medan City
}

\author{
Muhammad Yusrizal Adi Syaputra ${ }^{1}$, Dani Sintara ${ }^{2}$ \\ ${ }^{1}$ University of Medan Area, Medan, Indonesia \\ ${ }^{2}$ University of Muslim Nusantara Al Washliyah, Medan, Indonesia \\ agungsuharyanto@staff.uma.ac.id
}

\begin{abstract}
The enactment of Regional Regulation of Medan City Number 13 of 2011 and Regional Regulation Number 2 of 2016 have not accommodated the importance of Cultural values in the process of formation on spatial and region planning so that the RTRW development carried out by the Medan City government is only based on regulation alone without looking further into the social context and culture. According to Von Savigny's Theory, the formation of law must be based on people's souls (Volkgeist) as the raw material for the formation of law. Therefore, in the formation of regional regulations must pay attention to the cultural values of the indigenous people of an area. The inclusion of Malay cultural values in regional regulations in Medan City is a form of the realization of the state implementing Article $18 B$ paragraph (2) of the 1945 Constitution. Integration of the cultural values of the Malay people in Medan City into regional regulations is carried out through the implementation of the legislative functions of the Medan City Government and DPRD to accommodate and protect the soul of the nation from the original tribe of Medan City whose existence has been marginalized. Revitalizing the cultural value of the Deli Malay in Medan City into spatial and region regulation is a form of protection of the Medan city government towards the cultural, historical and social values of the Malay people in the Medan City.
\end{abstract}

Keywords: Regional regulation; Medan City; Malay Deli.

\section{Introduction}

The existence of Malay people of Medan City is now alarming when seen from its existence in the Government of Medan City. Medan Malay Society is currently just a symbol or Medan City Icon because there is still standing upright Royal Palace of the Sultanate of Deli, but if seen from its existence, actually the Malay Medan Deli community has been displaced by migrants such as the Tionghua, Batak, Karo, Mandailing, and Java. This situation becomes very alarming when there is no Deli Malay community involved as a whole in the Government in Medan City. Medan City Government which is currently headed by Malays, but the presence of Medan Mayor who comes from the Malays cannot represent the existence of the Medan Deli Malay community.

The diversity of migrant communities who are domiciled and eventually settled in the Medan City makes the existence of the Malay Medan Deli community displaced towards the outskirts of Medan. The existence of the Malay Deli in Medan is no longer found as a whole in a place in Medan City. The identity of the Medan Deli community has apparently been replaced by the arrival of outsiders.

The cultural value of the Medan Deli community is no longer something that is maintained its existence which has an impact on the loss of Malay identity in Medan. The influence of the loss of cultural values withered the Medan City has an impact on people's behavior and actions. In the field of Government, the loss of Malay cultural value of the Malay Medan City influences the management of Malay cultural assets in the form of Malay buildings 
or buildings in Medan. The loss of Malay culture also affects the application of the Malay cultural landscape in the management of natural resources and the environment. ${ }^{1}$

The current condition in Medan shows that the form and pattern of settlements / residential communities, land use patterns, community building architecture and government buildings that are not based on identity are sourced from the regional wisdom of the community that is the Malay community in Medan.

The modernization of Medan City has taken an impact on the implementation of Medan City Government. The development of the contemporary economy and the rapid pace of the global economy have made the Medan City one of the modern cities in Indonesia. No longer exists, the structure and policy patterns of the Medan City Government are based on the value of regional wisdom in Medan. All government policies stem from the positivism of the rules of the Central Government.

The Medan City Government no longer makes policies by looking at cultural and sociological anthropological aspects of the community, whereas in the formulation of policies as the implementation of a rule all aspects must be seen as consideration from the government. It aims to implement government policies that are representative of the community, creating harmony in social life and acceptance and implementation of government policies in the community.

One of the policies of the Medan City Government which is not in favor of the community is the formation of the Spatial and region plan of Medan City (RTRW) listed in Regional Regulation Number 13 of 2011 concerning the Spatial Planning of the Medan City Region in 2011-2031 and the Regional Regulation of the Medan City Number 2 of 2015 concerning Spatial Detailed Plan and Zoning Regulations of Medan City in 2015-2035 (Regional Regulation Number 2 of 2015).

Regional Regulation No. 13 of 2011 and Regional Regulation No. 2 of 2015 do not regulate the importance of Cultural Landscape in the process of spatial planning and regional planning and planning so that the RTRW development carried out by the Medan City government and private parties is only based on regulation alone without looking further into the social context and culture. The loss of attention on cultural anthropology, historical and social aspects in the form of cultural landscape makes Medan City as a Metropolitan City that is not friendly to the culture of the community, especially the Malay Medan Deli Community as the original people of Medan City.

This research entitled "Revitalization of Malay Cultural Values in Regional Regulation of Spatial and Region in Medan City"

Research with the title "Revitalization of Malay Cultural Values in Regional Regulation of Spatial and Region in Medan City" is conducted to examine the problems that are:

1) How is the integration of cultural values in the formation of Regional Regulations in Medan City?

2) How to revitalize the Cultural Values of Malay Medan Deli in the Implementation of RTRW Policy of Medan City?

\footnotetext{
${ }^{1}$ Cultural landscape is a model or form of built landscape, which is formed by a cultural value that belongs to a group of people that is associated with natural resources and the environment that exists in that place.
} 


\section{Review of Literatures}

\subsection{Theoretical Studies}

\subsubsection{Theory of the Law of the People's Soul (Von Savigny)}

Talking about theory, it refers to the opinion of Soetandyo Wignjosoebroto that the theory comes from the word "theoria" which comes from the Latin word meaning "contemplation" '. From the word thea in Greek which means way or outcome is a construction in the realm of human imaginative ideas about the realities that he encountered in his life experience. The socalled experiences are not only experiences that humans obtain from their sensory realms of life, but also from imaginative contemplative realms, especially in science with human subjects in their social life. Whatever the source, whether it is sensory experience or purely imaginative contemplative experience, the theory is a set of constructions built by concepts that are in the realm of human imaginative ideas. ${ }^{2}$

One legal theory developed in the formation of a country's law is the legal theory put forward by Von Savigny. Savigny developed the concept of "the soul of the nation (Volkgeist)" which was conceived by Gustav Hugo (1746-1861). Under the term of volkgeist, Savigny constructed his theory of law. According to Savignya there is an organic relationship between laws and the character or character of a nation. Law is only a reflection of volkgeist. Therefore, customary law that grows and develops in the volkgeist womb must be seen as the true law of life. The true law, not made, the law is found. Legislation is only important as long as it has the declarative nature of the true law. ${ }^{3}$

According to Savigny, in the formation of the main law is the excavation of legal values contained in the soul of a nation (people). The main legal management is to find principles and doctrines in the values of living law. This is obtained by knowing, discovering, and understanding the true legal values in people's lives. According to Savigny, the people's soul is not something that is decadent and static, but it is a mosaic constructed from historical processes, and will continue to process historically. Therefore it is necessary to complete the cultural and historical methods. ${ }^{4}$

The law does not stand alone and does not arise by chance, but is born from the inner awareness of the people, therefore the law develops along with the development of its people, and eventually it will disappear if the people lose their nationality.

According to Savignya, if the law makers want to formulate law in technical juridical principles, then the legislators must remain positioned as organs of public awareness. Legislators are tasked with giving shape to what is found in raw materials. The raw material in the formation of law according to Savigny is the duty of legal scientists to provide it. While the legislators formulated technically in the form of formal rules.

\subsubsection{Theory of Formation of Regional Regulation}

In law, theory is an imaginative concept of legal thinkers to issue ideas or reasoning on the law, the formation of law, enforcement, and law enforcement. According to Hans Kelsen,

\footnotetext{
${ }^{2}$ Soetandyo Wignjosoebroto, Tentang Teori, Konsep Dan Paradigma Dalam Kajian Tentang Manusia, Masyarakat Dan Hukumnya, Paper.

${ }^{3}$ Bernard L Tanya, Yoan N. Simanjuntal, Markus Y. Hage, Teori Hukum : Stategi Tertib Manusia Lintas Ruang dan Generasi, (Jakarta: Genta Publishing, Print.III, 2006), p. 103

${ }^{4}$ Ibid. p. 104
} 
legal theory shows the existence of law and how it exists. In this case, Hans Kelsen asserted that legal theory explains the validity of the law (applicable law) and the proper law, because Hans Kelsen argues that the law must be independent of the factors outside the law (pure legal theory).

According to the doctrine of concretization of law gradually, there is a process of delegation from basic norms in the constitution into norms that will be successively regulated graduatively by: ${ }^{5}$

1) Concreted by the legislative board.

2) Concreted by the administrative board.

3) Concreted by the judiciary board.

4) Concreted by habits in the community.

5) Re-concreted by private transactions.

The formation of statutory regulations in essence is the formation of legal norms that are valid and general in the broad sense. Statutory regulations are written decisions of the state or government that contain instructions or patterns of behavior that are general and binding. ${ }^{6}$ It means that it is not to identify a particular individual, so that it applies to every legal subject that meets the elements contained in the provisions regarding the behavior. ${ }^{7}$

Formal juridically, Law Number 12 of 2011 concerning Formation of Legislation in Indonesia which is used as a formal basis for the formation of legislation in Indonesia, including in the formation of Regional Regulations. Based on the provisions of Law Number 12 of 2011, Regional Regulations are the lowest legal products included in the hierarchy of Indonesian statutory regulations.

Regional regulations are legal products that enforce the position of regional governments as regional governments that can implement the principle of autonomy in regulating and organizing the government in their regions. Regional regulations become the basis for regional governments to form regulations at the regional level as implementing the provisions stipulated in a law. Although regional regulations are formed to carry out the tasks of regional autonomy and assistance, but in the implementation of the preparation of regional regulations, regional governments are guided by the formal and material principles as determined by Law Number 12 of 2011.

According to Zudan Arief Fakrulloh that regional legal products have a strategic role in encouraging the realization of regional autonomy. So, according to Zudan, that Regional Government Administrators must understand the regulatory order. ${ }^{8}$

The process of establishing regional regulations cannot be understood as the result of the configuration or will of the regional political elite. The formation of regional regulations must be able to respond to the real (real) needs of the regional community and development in an

\footnotetext{
${ }^{5}$ Munir Fuady, Teori-Teori (Grand Theory) Dalam Hukum, (Jakarta: Kencana, 2013), p. 140.

${ }^{6}$ Bagir Manan, in Yuliandri Asas-Asas Pembentukan Peraturan Perundang-Undangan Yang Baik: Gagasan Pembentukan Undang-Undang Berkelanjutan, ( Jakarta: Rajawali Press, 2013), Print. 4, p. 25

${ }^{7}$ Ibid.

${ }^{8}$ Zudan Arif Fakrulloh, Tertib Regulasi Dalam Pembentukan Produk Hukum Daerah, Journal of Lex Librum, Vol. IV, No. 2, June 2018, pp. 174-175. Orderly regulation is a process of making a good legal product in accordance with the laws and regulations and public interest which consists of elements of orderly authority, orderly procedure, orderly substance and orderly implementation
} 
area where there is a framework for implementing the principle of decentralization, the principle of deco-centration, and the principle of co-administration in a proportional manner. ${ }^{9}$

A quality regional legal product means that the legal product in terms of content and technical preparation in accordance with laws and regulations, can solve problems and answer the needs of the community. Whereas effective regional legal products mean that legal products that are made are not finished when they are determined, but the legal products according to needs, apply effectively or are effective or well-targeted or achieved its objectives and at the level of implementation can be beneficial to the community. ${ }^{10}$

\section{Research Methods}

This research is a normative legal research. The statute approach and the histors approach are used in addressing the problem. ${ }^{11}$ The data used are sourced from secondary data derived from primary, secondary and tertiary legal materials. Data Analysis is used qualitative data analysis.

\section{Discussion}

\subsection{Integration of Cultural Values in Formation of Regional Regulations in Medan City}

Citing Jeremy Bentham's opinion that there is a government that sees power and glory as the only means to achieve the public good, for that there is a government's indifference to society, so that people become victims of political selfishness from the government. ${ }^{12}$ The government's lack of attention to the happiness of the community makes the community a slave to their own country.

The presence of government in a country aims to protect, protect, prosper the community, not vice versa to make the community fear, oppressed, and violated the human rights and rights of its citizens. To that end, the government must be able to present a government that is honest, protective, just and upholds law and human rights.

The form of protecting the state in the community is outlined in the formation of state rules, namely the constitution and laws, as well as implementing regulations of the laws such as government regulations, ministerial regulations and regional regulations for the regional government level.

The quality of the rule of law established by the Government must be based on a philosophical foundation (filosofische grondslad) ${ }^{13}$, sociological (sociologicalche) ${ }^{14}$, and juridical (Juridische grondslag) ${ }^{15}$. The legal rules made by the Government must also meet the

9 King Faisal Sulaiman, Teori Peraturan Perundang-Undangan dan Aspek Pengujiannya, ( Yogyakarta: Thafa Media, 2017), p. 86

${ }^{10}$ Zudan Arif Fakrulloh, Op.cit. p. 175

${ }^{11}$ Peter Mahmud Marzuki, Penelitian Hukum, (Jakarta: Kencana Prenada Media Group, cet.7, 2011), p. 136

12 Jeremy Bentham, Teori Perundang-Undangan : Prinsip-Prinsip Legislasi, Hukum Regional regulationta, dan Hukum Pidana, Terj. Nurhadi, ( Jakarta: Nuansa Cendekia, 2019), p. 39

${ }^{13}$ The philosophical foundation illustrates that the regulations established take into account the outlook on life, awareness, and legal ideals which include the atmosphere of mysticism and the philosophy of the Indonesian nation which originates from the Pancasila and the Opening of the 1945 Constitution of the Republic of Indonesia.

${ }^{14}$ Sociological foundation is the basis that a rule of law must be able to meet the needs of the community in various aspects, not based on the interests of certain groups in society.

15 Juridical foundation is the basis that the legal rules formed must be based on higher rules (Legality) or have a 
formal and material requirements for the formation of legislation. This is in line with the formation of norms seen in view of legal positivism. Formal and material requirements are the determination of the creation of quality and sustainable rules.

According to Yuliandri, that one aspect that can be used as a measure to determine the quality of the formation of laws so that they have a sustainable meaning is the necessity of harmonization in the formation of laws, besides the need for synchronization. ${ }^{16}$

In juridical manner, the basics of establishing legislation in Indonesia are regulated in Law Number 12 of 2011 concerning Formation of Legislation (Law Number 12 of 2011).

Based on Law Number 12 of 2011 which classifies that the rule of law in Indonesia is based on levels or hierarchies consisting of ${ }^{17}$ :

1. The 1945 Constitution of the Republic of Indonesia (UUD 1945);

2. Decree of the People's Consultative Assembly;

3. Constitution / Government regulations of Substitute for the Constitution (Perppu);

4. Government Regulations;

5. Presidential Regulation;

6. Provincial Regulations;

7. Regency / City Regional Regulations

Legislation that is located outside the hierarchy is recognized and declared valid if it is based on the laws and regulations in the hierarchy. ${ }^{18}$ The rule of law outside from hierarchy in the form of regeling or beschikking must be synchronous and harmonious with the hierarchy of statutory regulations.

Regency / City Regulations (Perda) which are legal products at the regional level. A regional regulation is a form of law / norm that characterizes regions that have the right to regulate and manage the domestic affairs of their own regional government.

Based on Article 18 of the 1945 Constitution it is explained that the regions through the regional government have the right to regulate and manage their regional affairs according to the principle of autonomy and the task of assistance (medebewind). The order of the constitution in Article 18 of the 1945 Constitution aims to provide independence to the regions so that the regions can manage natural and human resources in their regions in accordance with the corridors of the Unitary Republic of Indonesia.

Article $18 \mathrm{~B}$ of the 1945 Constitution also provides space for regional governments to take care of the domestic affairs of their regions based on the specific nature or special nature of the region, and the State gives recognition to recognize and respect the customary law community units along with their traditional rights as long as they are still live and in accordance with the social development of the Indonesian people.

Material from the Regional Regulation as a government regulation at the regional level is based on ${ }^{19}$ :

\footnotetext{
legal basis (rechtsgrond) or legality.

${ }^{16}$ Yuliandri, Op.cit., p. 213.

${ }^{17}$ Article 7 paragraph (1) of Law Number 12 of 2011

18 The divergence pattern of national legal products in the hierarchical system of laws and regulations is not intended to dichotomize one legal product with another. The hierarchical system aims to clarify the legal position and legally binding force of each product of legislation in the national legal system.

${ }^{19}$ King Faisal Sulaiman, Op.cit. p. 93.
} 
1) All contents in the framework of the implementation of regional autonomy and coadministration tasks;

2) Must be able to accommodate the special conditions of the region or the potential of the region (regional content);

3) Regional regulation is a derivation or further elaboration of higher legislation

Medan City as a city that is famous for its modernization is a Compound City which was originally filled by Malay Deli ethnicity, but the current condition of the existence of Malay Deli in Medan City has faded and it is difficult to find its existence in daily life.

There are some areas in Medan that can still be found, the majority of Malay tribes of the Deli are in Medan Belawan subdistrict, Medan Marelan subdistrict, Medan Labuhan subdistrict, Medan Deli subdistrict, whereas before the independence of the Malays were native tribes (landowners) in Medan City.

Based on the results of research from Lamry mentioned that the high migration ethnics of Tionghoa, Indians, Java, Mandailing, Angkola, Toba, Simalungun, Minangkabau, Arabic, Aceh and others resulted in the removal of ethnic / ethnic Malays as ethnic hosts which also resulted in ethnic host on the shifting of customary rights to ethnic / tribal migrants in the Medan City. ${ }^{20}$ According to Reid, the migration of people to the Medan City began in 1915 through the organization of the Colonial Government from the north and south of Tapanuli. ${ }^{21}$

The Medan City in the early period of the gemeente reflected segmented residential namely ethnic villages such as Chinese village (Chinessewijk) in Kesawan, European village (Europeanwijk) in Polonia, Indian village (Indianwijk) in Madras, Malay village (Inlanderswijk) in Maksum City ${ }^{22}$. In 1909, almost all residents of Maksum City were Malay people. The arrival of immigrants then made the city of Maksum inhabited by several ethnicities. Before independence (1945), the Maksum City community consisted of ethnic Malays, Mandailing, Minangkabau, and Javanese. The naming of the Maksum City can be seen based on maps made in the Netherlands in 1915 and 1933 which later gave the name of the region the name "Ma'soem City ". ${ }^{23}$

As a result of the large number of ethnic migrations to Medan, eventually making Medan a city that does not have a dominant culture. This results in mastery over the economy, politics of government carried out by ethnic migrants, so that the ethnic host does not have a role and dominance in the economy or government. This situation justifies the opinion of Hendro Prabowo and Agus Suparman that without being equipped with other ethnic knowledge, the existence of transmigration and diaspora also causes the mapping of ethnic groups to become increasingly complicated both in Java and outside Java. As a result, several provinces and cities in Indonesia have become multicultural communities ${ }^{24}$.

\footnotetext{
${ }^{20}$ Muhammad Salleh Lamrry, Mereka yang Terpinggirkan: Orang Melayu di Sumatera Utara, (Kuala Lumpur: Pusat Teknologi Pendidikan Universitas Kebangsaan Malaysia, 1996), p. 2

${ }^{21}$ Hidayat and Erond L. Damanik, Batak Dan Bukan Batak: Paradigma Sosiohistoris Tentang Konstruksi Identitas Etnik Di Kota Medan, 1906-1939, Journal of Sejarah Citra Lekha, Vol. 3 , No. 2, 2018, pp. 71-87

22 Ibid.

${ }^{23}$ Ahmad Fakhri Hutauruk and Dwi Rizky Adelina, Kota Maksum: in Lintas Sejarah 1905-1946, Journal of Criksetra, Volume 5, No. 10, August 2016, p.137.

${ }^{24}$ Hendro Prabowo and Agus Suparman, Masalah Etnisitas Dan Tata Ruang Di Indonesia, Proceeding. Seminar Nasional PESAT 2005, Auditorium University of Gunadarma, Jakarta, 23-24 August 2005, p.26.
} 
The development of ethnic identity by migrant groups has formed a new system in Medan in the fields of law, government and economy. Medan is no longer an area that only belongs to Malay ethnic groups but has been dominated by migrant ethnic groups.

During the reign of Sultan Deli and the Dutch Colonial Power, the pattern of settlement in the Medan region consisted of three main classes, namely ${ }^{25}$ :

1) Europese Wijk, which is a residential area specifically occupied by residents of the European class;

2) Chinese Wijk, which is a residential environment inhabited by Chinese people only;

3) Settlement environment, which is specifically occupied by indigenous people.

In the field of law and government, legal products are no longer found in the form of regional regulations in the Medan City based on their formation based on the values of regional wisdom through the application of cultural landscapes into regional regulations in the Medan City.

Regional regulations made by the Medan City Government and the Medan City DPRD are only oriented towards the macro economy, infrastructure, business, but have not represented the interests of the regional ethnicity. This has an impact on the elimination of the existence of ethnic Malay and Malay cultural loss in the Medan City.

Based on the theory of the people's soul (volkgeist) that the legislator must work together with legal scientists to find the people's soul as the raw material for forming the law. In this case, the Medan city government and the DPRD as regional legislators should work together with legal scientists (academics) to find the souls of the people of Medan, especially ethnic Malay communities as native people of Medan to be accommodated and then incorporated and arranged formally as raw materials in the formation of regional regulations in the Medan City. Disregarding the will and soul of the original Medan City community (Malay Deli) will make the souls of the people of the Malay tribe of the Deli lost, so that its existence will not be found again in Medan and will have an impact on the disappearance of the regional identity of Medan City as an area that has cultural customs that have lived in the Medan City.

The Regional People's Representative Assembly (DPRD) of Medan City is principally a regional legislator who has the right of initiative in realizing the will of the community to be accommodated into regional regulations, thus, the resulting regional regulations will become regional regulations that have a foundation of values and soul from the community, especially from the indigenous people in the Medan City.

DPRD becomes an institution that can integrate the cultural values of the Malay people to be systematically and systematically formulated through regional regulations in order to obtain legal certainty. Integration of the cultural values of the Malay people of Medan through regional regulations will restore the regional existence of the original people of Medan, which has been a cultural symbol of Medan. Integration of Malay cultural values can be included in regional regulations does not mean discriminating against other ethnic groups as migrant communities who are now the majority community in Medan, only by integrating Malay cultural values through regional regulations, so the position and existence of Malay cultural values cannot be replaced by migrant tribes in Medan.

Maintaining the existence of cultural values withered Medan City through regional regulations and Medan City government policy is in the context of implementing Article 18 B paragraph (2) of the 1945 Constitution which states that "the State recognizes and respects the

${ }^{25}$ Ibid. p.29. 
customary law community units along with their traditional rights as long as they are still alive. And in accordance with community development and the principles of the Unitary State of the Republic of Indonesia, which is regulated in the law." If the culture of Malay Deli in Medan is lost, then there is no longer any state obligation to recognize and respect the values of the indigenous Malay Deli community as an ethnic group in the city of Medan in particular, and Indonesia in general. So thus, the state through its government will act with its policies that no longer protect and recognize the cultural existence of the Malay Deli community on the grounds that the Malay Deli people have no longer existed, because they no longer live and develop in Medan.

\subsection{Revitalization of Malay Medan Deli Cultural Values in Implementing RTRW Policy of Medan City}

Efficiency and effectiveness in the process of establishing a Regional regulation can be seen in the formal process of establishing a Regional regulation in the DPRD or in the Regional Government. Regional regulations that have special content are required to have an "executive preview" mechanism, for example Regional Regulations on APBD designs, APBD Amendments, Regional Bills on Accountability for implementing APBD, Regional Tax Bills and Regional Retribution and Regional Spatial Planning. ${ }^{26}$

According to Ahmad Jazuli that with the development of an area in the City or village in addition to having a positive impact also caused environmental problems. The decline in environmental quality that causes natural disasters is caused by violations of spatial planning by the Government. ${ }^{27}$

One of the tasks of government carried out by the Regional Government of Regency / City level is the formation of RTRW as stipulated in:

a. Article 12 of Law Number 23 of 2014 concerning Regional Government as amended by Act Number 9 of 2015 concerning Second Amendment to Law Number 23 of 2014 concerning Regional Government;

b. Article 14 of Law Number 26 of 2007 concerning Spatial Planning;

c. Government Regulation No. 22/1973 concerning Expansion of Municipal Areas;

d. Government Regulation Number 15 of 2010 concerning Implementation of Spatial Planning

e. Government Regulation Number 8 of 2013 concerning Accuracy of Spatial Planning Maps

f. Presidential Regulation Number 62 of 2011 concerning Spatial Planning for Urban Areas of Medan, Binjai, Deli Serdang, and Karo;

g. Regulation of the Minister of Public Works Number 20 / PRT / M / 2011 concerning Guidelines for the Preparation of RDTR and Regency / City Zoning Regulations;

h. Regional Regulation Number 13 of 2011 concerning Medan City Spatial Planning 20112031

The importance of a regional spatial layout is to determine the location in an area, whether or not infrastructure development can be carried out in harmony with the surrounding environment and not damage the environment.

\footnotetext{
${ }^{26}$ King Faisal Sulaiman Op.cit. p.95.

${ }^{27}$ Ahmad Jazuli, Penegakan Hukum Penataan Ruang Dalam Rangka Mewujudkan, Pembangunan Berkelanjutan, Journal of RechtsVinding, Vol. 6 No. 2, August 2017, pp. 272-273.
} 
Based on the provisions of Article 1 number 16, it is explained that: "Spatial and region plan of Medan City or RTRW, is a general spatial plan of the regional area, which is a translation of the Provincial RTRW, and which contains the objectives, policies, regional spatial planning strategies, regional spatial structure plans, plans regional area spatial pattern, stipulation of regional area strategic area, stipulations on regional area spatial utilization, and provisions on regional spatial use control".

The implementation of Medan City Development through the RTRW foundation which is regulated through Regional regulation No. 22015 is complemented by zoning regulations for regional areas in Medan City. This is needed to determine the requirements in the use of space arranged according to each block or zone for which each block / zone has its own designation.

In Regulation No. 2 of 2015 it is stated that there are several blocks / zones, including:

1. Protected Zone;

2. Mangrove Zone or Nature Reserve;

3. Regional Protection Zone;

4. Green Open Space Zone;

5. Disaster-Prone Zone;

6. Cultivation Zone;

7. Non-Green Open Space Zone;

8. Agricultural Zone;

9. Housing Zone;

10. Trade and Services Zone;

11. Office Zones;

12. Industrial Zone;

13. Public Service Facility Zone;

14. Special Zones.

In the implementation of regional Protection Zones are divided into several sub zones, There are:

a. Coastal Border Sub-zone

b. River Border Sub-zone

c. Lake Border Sub-zone

d. Paluh Border Sub-zone

e. Channel Border Sub-zone

f. Polder Border Sub-zone

g. Trench Border Sub-zone

h. Railway Track Borders Sub-zone

i. Extra High Voltage Air Channel Sub Zones or High-Voltage Air Ducts Green open space zones, classified into:

a. Green Park Open Space Sub-Zone

b. Green Park Open Space Sub-Zone

c. Green Open Space Public Burial Park Sub-Zone

d. Green Open Space Sub-Zone Tourism Area

e. Green Forest Urban Open Space Sub-Zone

f. Green Open Space Sports Sub-Zone

g. Green Space Open Sub-Zone Green Road

h. Private Green Open Space-Zone 
Disaster Prone Zone is classified as:

a. Tidal Disaster Prone Sub-Zone;

b. Flood Prone Sub-Zone;

c. Fire Disaster Prone Sub -Zone;

d. Tsunami Prone Sub -Zone;

The Non Green Open Space Zone in Medan City is divided into several sub, namely:

a. Non Green Pavement or Paved Open Space Sub-Zone

b. Non Green Open Space Sub-Zone blue open space (body of water)

Housing zones are divided into several sub, namely:

a. High Density Housing Sub-Zone

b. Medium Density Housing Sub-Zone

c. Low Density Housing Sub-Zone

The Trading Zone is divided into:

a. Trading Sub-Zone

b. Commercial Service Sub-Zone

The Industrial Zone consists of:

a. Industrial Sub-Zone, divided into Light / Small / Non-Pollutant Industries, Home / Medium Industries and Large Industries

b. Warehousing Sub-Zone

Special Zones consist of:

a. Defense and Security Sub-Zone;

b. Other Special Sub-Zone

Medan City as a Metropolitan City already has rules on Spatial Planning and territories which should regulate infrastructure and development matters in Medan City. In fact, that the implementation of infrastructure development by the Medan City Government and Private Parties has not paid attention to and considered cultural values but only based on business orientation. Many areas in Medan City are seen as out of harmony with the environment and social conditions at the lower levels.

Medan as a Metropolitan City still has areas that are categorized as slums. Some of the locations included in the slum area are North Medan, Belawan Medan, Labuhan Medan, Marelan Medan, Medan Tembung, Medan Denai, Medan Sunggal and Medan Perjuangan. The slum area in the northern area of Medan is a fishermen housing estate located in Medan Belawan, and on the Deli River and in the railway area.

There are several areas in the Medan City where there are currently conflicts between the government and the community, namely the Sari Rejo area in Medan Polonia Subdistrict. Conflict between the community and the Air Force (AU). The inconsistency of the Government in resolving conflicts between the community and the Air Force in the Sari Rejo area is evidenced by the unclear status of community land in the Sari Rejo area. This is different from the existence of the Polonia CBD Shopping Complex, which is located next to the Soewondo Military Base.

The existence of the Polonia CBD shopping complex and residential area around Soudondo Lanud shows that Regional regulation Number 13 of 2011 and Regional regulation Number 2 of 2015 do not function properly, because when looking from these areas, the housing complex around Polonia directly borders the Deli River easily operates and developing. 
Pursuant to Government Regulation Number 15 of 2010 concerning Spatial Planning, derivatives of Law Number 26 of 2007 concerning Spatial Planning are regulated that Regency / City areas have the authority to manage watersheds, both for planning, implementing, monitoring, evaluating, and developing as well as supervision with certain scale that has been set by:

a. Regency / City of at least 1: 50,000;

b. Provinces are used with a minimum accuracy level of 1:250,000;

c. National scale 1: 1000,000

These provisions are in line with or compatible with Law No. 23 of 2014 because the Sub Arrangement of Spatial Planning is basically included in the Government Affairs in the field of Public Works and Spatial Planning, divided into:

1. Central Government for the Implementation of national spatial planning and the implementation of inter-state spatial planning cooperation.

2. Implementation of provincial spatial planning.

3. Implementation of regency / city Regional spatial planning

Based on the provisions of Article 2 of Government Regulation Number 15 of 2010 in conjunction with Government Regulation of Number 37 of 2012 that Watershed Management is carried out in accordance with the spatial planning and water resources management patterns.

Regional Governments that conduct omission (ignore) activities that are related to the watershed area that cause consequences for the environment and society, basically the Regional Government has taken actions that are contrary to the laws and regulations, namely:

a. Law Number 7 of 2004 concerning Water Resources

b. Law Number 32 of 2009 concerning Environmental Protection and Management;

c. Government Regulation Number 38 of 2011 concerning Rivers

d. Minister of Public Works and Public Housing Regulation No. 8 of 2015 concerning Establishment of Irrigation Network Border Line

But in reality, development on the banks of the river or river banks in the Medan City continues to occur and even more in number. This is due to the indecisiveness of the Medan City government in setting regulations regarding the construction of buildings along the river bank. In addition, the act of granting permits to build buildings and issuing certificates of ownership granted to residents who build buildings on river banks or river banks is one of the biggest obstacles on river banks which cannot be relocated or repaired.

The Medan City Government in making the Medan City regional development policy inconsistent with existing rules. Even in Regional regulation Number 13 of 2011 and Regional regulation Number 2 of 2015, it does not emphasize that the importance of development in Medan must also look at the condition of social, cultural, and economic structures. Regional regulation Number 13 of 2011 and Regional regulation Number 2 of 2015 are the legal basis for the Medan City Government to carry out development in Medan City by taking into account the Spatial and region plan of Medan City (RTRW).

In addition to the problems of residential areas, the issue that must be a concern of the Medan City government is the placement and preservation of historical buildings. This is evidenced by the many historical buildings that were demolished, over functioned, and not well maintained. In fact, with the well preserved historical building can be one of the attractions in the Medan City that can bring regional income.

Medan City cannot be categorized as a City that preserves cultural and historical buildings. Medan has been changed to the City of Glass and Tall Buildings that have an impact 
on the environment. The threat of global warming and environmental damage from the rise of high rise buildings must be anticipated by the Medan City Government. This is evidenced by, some areas in the Medan City become flood-prone areas when it rains, waste management is not optimal, slums are still often found and damage to historical sites in the Medan City. Therefore, there must be a progressive policy from the Medan City Government in dealing with the current environmental, social and cultural damage.

Community involvement and non-governmental organizations as well as the cultural community of people in the Medan City can be a solution in forming participatory regional policies. Medan City Government can jointly with stakeholders in determining regional policies to implement the Spatial Planning Law so that the implementation is oriented to the environment, social and culture so that there is no bias and confrontation of interests between the community and regional government.

The implementation of the Medan City Government's spatial policy is carried out by the Medan City Spatial Planning Agency as the executor of the Medan City Government's governmental duties. Therefore, the Spatial Planning Office can form strategic and humanistic policies based on the environment, social and culture. For example, in granting permits for building hotels, apartments and malls, they must pay attention to the concept of spatial planning and the Medan City area so that the implementation of the permit does not disturb or damage the social concept of the regional community.

Malay cultural values which are the original people of Medan City must get protection and an appropriate place in the Medan City regional government. Maintaining and preserving and not replacing the new historical buildings of the Malay Deli in Medan City society is a form of protection from the Medan City Government to the Malay Medan Deli community. The inclusion of Malay cultural ornaments in every government building, office building and public facilities is a form of protection of the Medan City government towards the values of the Malay Medan Deli community in order to continue to exist, live and thrive amid modernization in Medan.

\section{Conclusion}

Medan City as a Metropolitan City that actually has a regional ethnicity (ethnic origin) which is a symbol of the culture of the people of Medan City and is known throughout the World must maintain the existence of the Malay community. One form of integration of the cultural value of Malay Deli in order to stay alive and develop is to integrate it into raw material in the formation of regional regulations, so that the existence of the Malay Deli in the Medan City gets legal certainty.

The importance of the Malay Deli cultural values included in the formation of the Medan City Government policy in the field of RTRW is to make the Medan City a Modern City that does not eliminate the historical, cultural, and sociological values of the Malay Deli community as the original people of Medan. The RTRW policy of the Medan City Government is not merely concerned with economic and business interests, but also must prioritize the social will of the people of Medan.

Formation of regional regulations of Spatial and region that accommodate areas that have historical, cultural and social values will maintain historical buildings in the Medan City. The formation of cultural and historical areas is one form of the implementation of Medan's regional government policy to revitalize the cultural, historical and social values of the Malay people of Medan Deli. 


\section{References}

Ahmad Fakhri Hutauruk and Dwi Rizky ADelina, Kota Maksum: Dalam Lintas Sejarah 19051946, Journal of Criksetra, Volume 5, No. 10, August 2016.

Ahmad Jazuli, Penegakan Hukum Penataan Ruang Dalam Rangka Mewujudkan, Pembangunan Berkelanjutan, Journal of RechtsVinding, Vol. 6 No. 2, August 2017.

Bernard L Tanya, Yoan N. Simanjuntal, Markus Y. Hage, Teori Hukum : Stategi Tertib Manusia Lintas Ruang dan Generasi, Jakarta: Genta Publishing, Print.III, 2006.

Hendro Prabowo and Agus Suparman, Masalah Etnisitas Dan Tata Ruang Di Indonesia, Proceeding. Seminar Nasional PESAT 2005, Auditorium Universitas Gunadarma, Jakarta, 23-24 August 2005.

Hidayat and Erond L. Damanik, Batak Dan Bukan Batak: Paradigma Sosiohistoris Tentang Konstruksi Identitas Etnik Di Kota Medan, 1906-1939, Journal of Sejarah Citra Lekha, Vol. 3 , No. 2, 2018.

Jeremy Bentham, Teori Perundang-Undangan : Prinsip-Prinsip Legislasi, Hukum Regional regulationta, dan Hukum Pidana, Terj. Nurhadi, Jakarta: Nuansa Cendekia, 2019.

King Faisal Sulaiman, Teori Peraturan Perundang-Undangan dan Aspek Pengujiannya, Yogyakarta: Thafa Media, 2017.

Muhammad Salleh Lamrry, Mereka yang Terpinggirkan: Orang Melayu di Sumatera Utara, Kuala Lumpur: Pusat Teknologi Pendidikan Universitas Kebangsaan Malaysia, 1996.

Munir Fuady, Teori-Teori (Grand Theory) Dalam Hukum, Jakarta: Kencana, 2013.

Peter Mahmud Marzuki, Penelitian Hukum, Jakarta: Kencana Prenada Media Group, Print.7, 2011.

Soetandyo Wignjosoebroto, Tentang Teori, Konsep Dan Paradigma Dalam Kajian Tentang Manusia, Masyarakat Dan Hukumnya, Paper.

Yuliandri. Asas-Asas Pembentukan Peraturan Perundang-Undangan Yang Baik : Gagasan Pembentukan Undang-Undang Berkelanjutan, Jakarta: Rajawali Press, 2013.

Zudan Arif Fakrulloh, Tertib Regulasi Dalam Pembentukan Produk Hukum Daerah, Journal of Lex Librum, Vol. IV, No. 2, June 2018.

\section{Constitution Regulations}

The 1945 Constitution of the Republic of Indonesia

Law Number 12 of 2011 concerning Formation of Legislation

Law Number 23 of 2014 concerning Regional Government

Medan City Regulation Number 2 Year 2015 concerning Spatial Planning Detailed Plan and Medan City Zoning Regulation 2015-2035 